\title{
HOUSEHOLD WILLINGNESS TO PAY FOR IMPROVED SOLID WASTE MANAGE- MENT IN BATTICALOA, SRI LANKA
}

\author{
Krishnal Thirumarpan * and MSA Dilsath \\ Department of Agricultural Economics, Faculty of Agriculture, Eastern University, Vantharumoolai, \\ Sri Lanka
}

Accepted: $10^{\text {th }}$ June 2016

\begin{abstract}
Disposal of solid waste is a priority environmental problem in Sri Lanka and at present it has become a national concern. In a way of treating waste, this study was focused on analyzing the willingness to pay of the households for an improved solid waste management service in Eravur Urban Council, in Batticaloa, Sri Lanka. Proportionate sampling was done and from five Grama Niladhari divisions a total of 100 households were studied. Binomial logistic regression was employed to find out the determinants of household willingness to pay. Results revealed that the average household income and expenditure were Rs 34,440 and Rs 32,850 per month respectively. Mean quantity of solid waste generated by households was $2.61 \mathrm{~kg} / \mathrm{day}$. Fifty nine percent of the households were willing to pay for an improved service. Most of the households $(\mathbf{8 6 . 4 5 \%})$ preferred a monthly payment through collection tickets. Mean willingness to pay of households was Rs 59.92/month. The logistic regression results revealed that household size and household expenditure significantly and positively influences the household willingness to pay. Quantity of waste generated, number of times disposing the waste and gender had a negative coefficient and were significant $(\mathbf{p}<\mathbf{0 . 0 5})$. It is recommended that households should be educated on effective solid waste disposal through regular sensitization programmes by a collaborative effort of key stakeholders in the solid waste management.
\end{abstract}

Key words: Binomial logistic regression, Solid waste, Willingness to pay

\section{INTRODUCTION}

Solid waste, especially Municipal solid waste is a pressing problem in the world. With the increasing urbanization, the management of solid waste is becoming more complex in most of the developing countries (Medina, 2010).

According to the United Nations Environment Programme (2004), solid waste generation is an increasing global environmental and public health problem. Changing economic trends and rapid urbanization also complicate solid waste management in developing countries.

Sri Lanka is facing serious difficulties with regards to municipal solid waste management. Vidanaarachchi et al., (2006) in his study predicted that the country would have a municipal solid waste generation rate of $1.0 \mathrm{~kg}$ per capita/ day, and an urban population of $42.6 \%$ of the

*Corresponding author: thirumarpan@gmail.com total population by 2025 . But Local authorities in Sri Lanka have failed to deliver the required levels of waste management services. At present, only a part of the waste stream is collected by local authorities, due to the shortage of efficient vehicles and skilled labourer. The remaining fraction is being illegally dumped on road sides, forest areas, river banks and low lying marshes, thereby significantly reducing value of the environment. Although haphazard solid waste disposal has been identified to be one of the major causes for environmental degradation in the National Action Plan of Sri Lanka, the most common method of municipal solid waste disposal still remains to be open dumping, leading to many environmental and health problems (Gunawardana, et al., 2009). Furthermore, poor waste management systems coupled with tropical climatic conditions contribute to increasing environmental pollution at local, re- 
gional, and global levels (Inazumi, et al., 2011).

In Sri Lanka, many districts experience waste management problems. Batticaloa district has the biggest demand for proper waste management and generation of waste is increasing rapidly year by year (City profile, Batticaloa, 2005). According to the Eravur Urban Council Report (2014), an estimated 20 metric tons of solid waste is being generated in the Urban Council area every day. And the amount of solid waste generated per individual ranges between $0.50 \mathrm{~kg}$ and $0.625 \mathrm{~kg}$ daily. In a way of treating waste, the concept on willingness of people to dispose the waste is becoming more popular. But the problems observed were lack of disposal site and lack of financial assistance compared to solid waste generation in Eravur Urban Council. During the flood periods, waste had been carried out into lagoon and it was dug out by animals and birds and was spread all over the area. Besides, the Children Park located near the Eravur lagoon got affected by this. By considering all these facts, a proper disposal of solid waste in Eravur Urban Council is an urgent need. Therefore this study was focused on analyzing the willingness to pay of the households for an improved household solid waste management service in Eravur Urban Council.

\section{MATERIALS AND METHOD}

\section{Study site and sampling}

This study was conducted in 5 Grama Niladhai (GN) divisions of Eravur Urban Council area in Batticaloa district which were coming under the Eravur Town Divisional Secretariat division. Eravur Urban Council has 15 GN divisions. Proportionate sampling was done and from Eravur-03A, Eravur-03, Eravur-02C, Eravur-02A, Eravur-01B GN division 27, 23, 18, 16, 16 samples were collected respectively. Thus the final sample comprised of 100 household.

\section{Data collection and analysis}

Primary and secondary data were used in the study. Primary data were taken from personal interviews with household head using a questionnaire. Solid wastes from 100 households

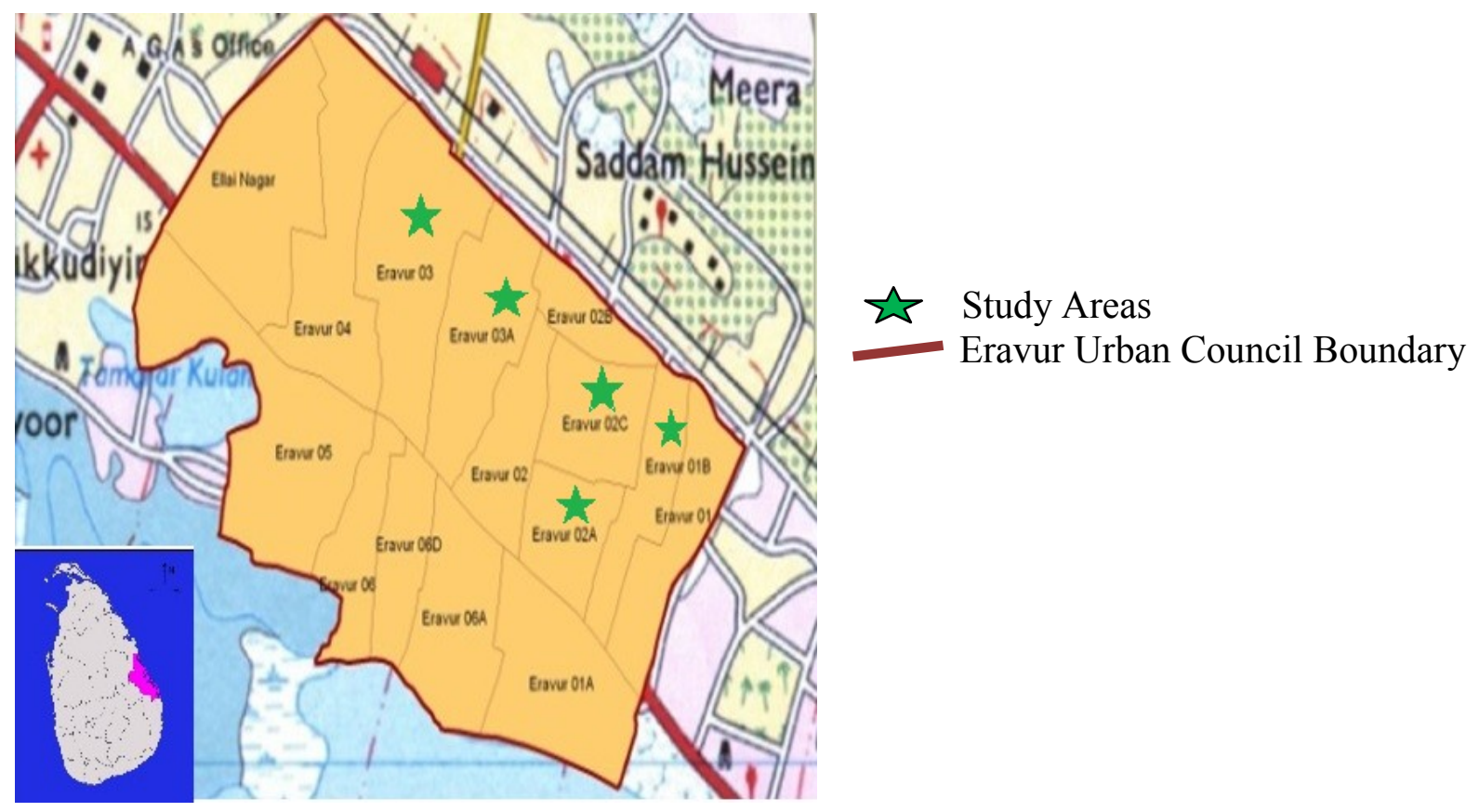

Figure 1: Location of the study area (Source- Eravur Urban Council, Batticaloa) 
were weighed during the survey to determine the amount of solid waste generated each day by households in the study area.

Secondary data were obtained from the Eravur Urban Council, Divisional Secretariat (Eravur Town), National Solid Waste Management Support Centre (NSWMSC) etc.

Contingent Valuation method was used for valuation. Descriptive statistics and frequency distribution were used to analyze the socioeconomic characteristics of the respondents. The Binomial logistic regression was employed to find out the determinants of household willingness to pay.

\section{RESULTS AND DISCUSSION}

Socio demographic and economic profile of households

The age of household head ranges between 25 to 71 years and majority (39\%) of them were in the age category of 40 to 50 years. Majority of the household heads in the surveyed area were male $(86 \%)$ as well as most of the study participants were married (99\%) (Table 1). Results also indicated that most of the household heads were educated up to secondary level (55\%) followed by $28 \%$ up to tertiary level. Majority of the household heads $(39 \%)$ were involved in business activities and $21 \%$ of them involved in government job. The mean family size of household was 4.2

Table 1: Individual level information of the head of the household

\begin{tabular}{ll} 
Individual Level Information & Percentage \\
\hline Sex & \\
Male & 86 \\
Female & 14 \\
\hline Civil Status & \\
Single & 1 \\
Married & 99 \\
\hline Educational Level & \\
Primary (Grade 1 to 5) & 13 \\
Secondary (Grade 6 to A/L) & 55 \\
Tertiary (Diploma, Degree etc.) & 28 \\
Other (Vocational) & 1 \\
No Schooling & 3 \\
\hline Employment & \\
Government Employee & 21 \\
Private Employee & 20 \\
Self-Employed & 16 \\
Businessperson & 39 \\
Unemployed & 2 \\
Retired & 2 \\
\hline
\end{tabular}


persons in the surveyed area and the mean household income was Rs 34,440 per month. The average household expenditure was Rs 32,850 per month.

\section{Major issues in Eravur environment}

About thirty one percent of the total household heads stated that household waste management as the major problem in the study area. Other major problems identified were mostly sewage pollution from pits and toilets $(10 \%)$, cutting down trees $(3 \%)$ and pollution from factories $(2 \%)$. Fifty four percent of the household heads stated that there were no issues in their environment.

\section{Household waste storage methods}

The results indicated that majority $(82 \%)$ of the households used plastic bags for storage of household waste, fourteen percent used pile in the yard, ten percent used open containers and six percent used closed containers. Lack of standard equipments affects solid waste management, plastic bags carry risks to solid waste collectors during collection especially if there were sharp objects inside the bags. And the plastic bags that are not well attended could easily be destroyed by animals resulting into littering of wastes in streets (Yusufu, 2007). Furthermore it increases the time compared with standardized container therefore lowering efficiency (Zurbrugg, 2003).

Quantity of solid waste generated and household willingness to pay for solid waste management

The amount of waste generated by households per day was measured and is shown in Table 2. The average quantity of solid waste generated by households was $2.61 \mathrm{~kg} /$ day which is comparable with a study by Wijerathna et al. (2011), in Gampola Urban Council where the daily per capita household waste generation was $0.39 \mathrm{~kg} /$ person/day. The average solid waste load of the Eravur municipality was 20,000 kg (Eravur Urban Council, 2014). The results also revealed that the households that were not willing to pay produced larger

Table 2: Independent sample T-test between willingness to pay and not willingness to pay for quantity of solid waste

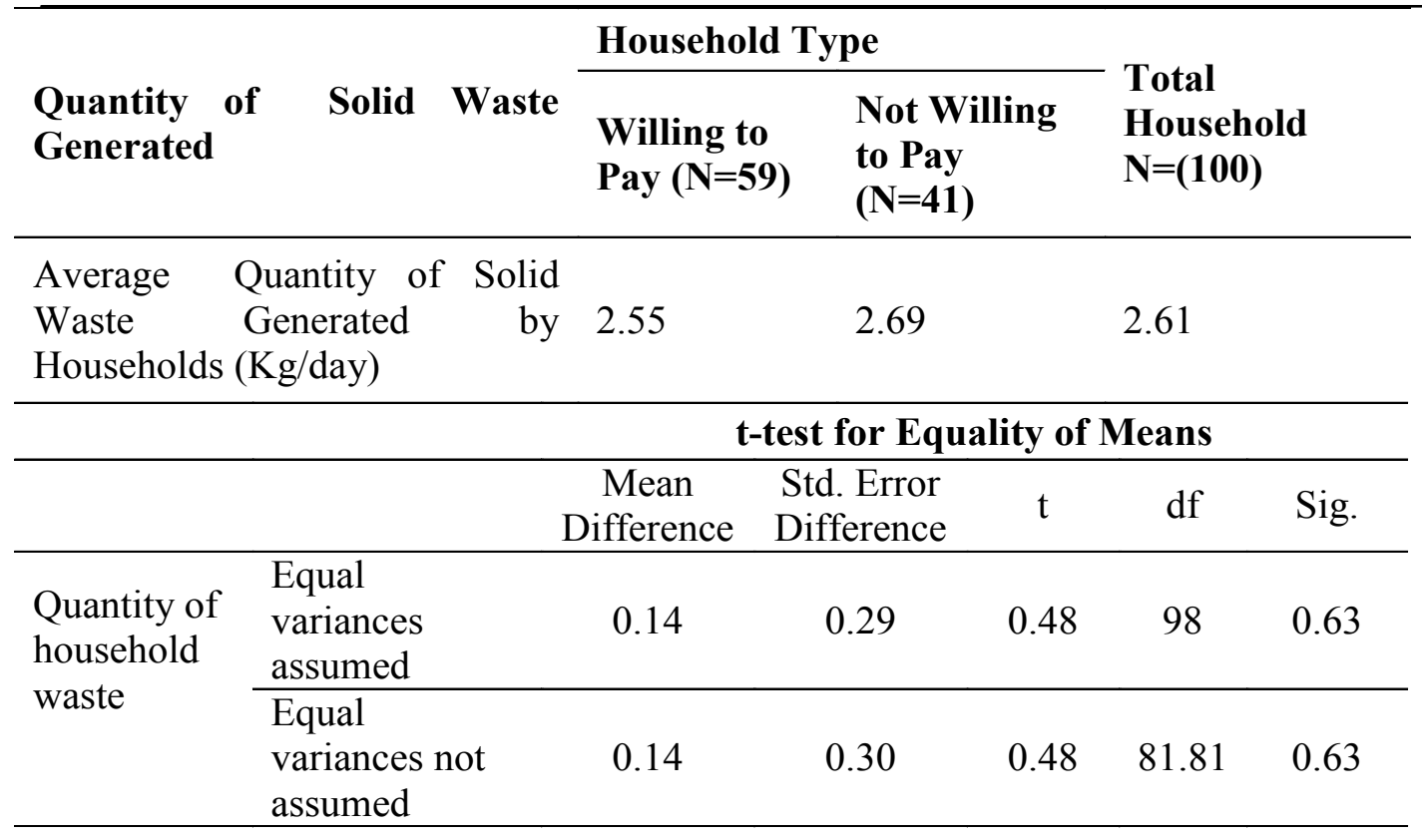


amount of waste when compared to households which were willing to pay for an improved municipal solid waste management service. But the $t$ test results showed there was no significant difference $(p>0.01)$ between those who were willing to pay and those who were not willing to pay for an improved municipal solid waste management.

\section{Method of waste disposal adopted by household}

The study indicated that majority of the households were dumping the waste in Urban Council vehicles $(75 \%)$. Among the sample households, only one percent of the households do not have any of the fixed methods to dispose their waste. Twelve percent of the households were dumping waste on road side. These improperly dumped wastes were the breeding grounds for insects, pest and infectious diseases and also produce toxic gases, which spread odour around the dumping place (Ashish and Uttam, 2013). And 7\% were dumping in backyard. And the rest were disposing the waste using different methods such as dumping in backyard and urban council vehicles $(2 \%)$, Dumping in urban council vehicles and road side (2\%) and Dumping in backyard and road side (1\%). Inefficient and inappropriate ways of disposing waste had created unpleasant scene, creating a serious threat to public health, including air and water resources pollution. But according to a household survey conducted for the municipality of Moratuwa, municipal waste collection was available to only $56 \%$ of the households. About 20\% of the households dump their waste on the roadside and $8 \%$ dump the waste into pits in their own back yards. (Bandara and Hettiarachchi, 2008).

\section{Household opinion of the Urban Council collection service}

Most of the households (43\%) were very satisfied with the existing collection service of the Urban Council. Twenty seven percent of the households were reasonably satisfied and twenty five percent were not satisfied. Most of the households who are willing to pay for an improved municipal solid waste management service believe that the urban council is providing good collection services. The remaining five percent do not have any idea about the Urban Council services.

\section{Reason for dissatisfaction with the Urban Council collection service}

About sixty eight percent of the household stated that the frequency of the Urban Council collection service was not enough which means the interval between the collections is too long. Twenty four percent of the households mentioned that the service of the urban council was not reliable and eight percent of the household stated both reasons.

\section{Household concern about environmental safety and acceptability of final disposal}

About $56.25 \%$ of the household felt that the disposal of such collected waste was not environmentally safe and $33.33 \%$ of the household felt that the disposal of such collected waste was environmentally safe and the remaining $10.42 \%$ of the household could not explain whether it is environmentally safe or not. Differences in attitudes may be due to differences in the background of respondents.

\section{Satisfaction level on frequency and time of collection of Household waste by Urban Council}

Thirteen percent of the household preferred daily solid waste collection. Majority (45\%) would like the Urban council to collect waste twice a week followed by thirty one percent of households preferred thrice a week and nine percent stated that they preferred to have the collection service once a week. Rest of the households didn't have any idea on collection services. Data also revealed that eighty seven 
percent of the households preferred to have their solid waste collected at any time between 07.00 am to $10.00 \mathrm{am}$, nine percent of the household preferred to have their solid waste collected at any time between $1.00 \mathrm{pm}$ to $4.00 \mathrm{pm}$ and remaining household preferred to have their solid waste collected at any time between 10.00 am to $1.00 \mathrm{pm}$.

\section{Household willingness to participate in various solid waste management practices}

From the result it revealed that higher percentage of the household heads know composting and recycling. Sixty two percent of the household heads were willing to separate their household waste for the recycling program (Table 3).

Although seventy five percentage of the household heads heard about the term "composting", only fifty percent of the household heads were willing to participate in compost production program.

\section{Willingness to pay of households for an im- proved municipal solid waste collection ser- vice}

Reason for Willingness to pay: According to the survey results about $38.9 \%$ of the household heads stated that they wanted to pay for an improved service because they believe that solid waste collection service improvement is important for the health of the household. $38.1 \%$ of the household heads stated that it is needed for a better quality of the environment (Table 4).

Reasons for not Willing to pay: According to the survey results about $35.9 \%$ of the household heads reasoned out that as their income

Table 3: Household willingness to participate (Multiple Response)

\begin{tabular}{|c|c|c|}
\hline \multirow{3}{*}{ Willingness to participate } & \multicolumn{2}{|c|}{$\begin{array}{l}\text { Household willingness to } \\
\text { participate }(\mathrm{N}=100)\end{array}$} \\
\hline & Yes & No \\
\hline & Percentage & Percentage \\
\hline Have you ever heard about composting? & 75 & 25 \\
\hline Have you ever heard about recycling? & 65 & 35 \\
\hline $\begin{array}{l}\text { If a recycling program was set up, would you be willing to } \\
\text { separate the waste into separate bags for collection } \\
\text { purposes? }\end{array}$ & 62 & 38 \\
\hline $\begin{array}{l}\text { Would you be willing to pay for pickup of waste materials } \\
\text { from your home? }\end{array}$ & 59 & 41 \\
\hline $\begin{array}{l}\text { Would you be willing to participate in a program for } \\
\text { compost making by using kitchen and yard waste? }\end{array}$ & 50 & 50 \\
\hline $\begin{array}{l}\text { If you will be paid for every plastic bottle that you returned } \\
\text { to the grocery store, would you participate in a program to } \\
\text { return the plastic bottles? }\end{array}$ & 28 & 72 \\
\hline $\begin{array}{l}\text { Would you like more information about how and what } \\
\text { types of waste you can compost, reuse and recycle in order } \\
\text { to reduce the amount of waste that you need to get rid of? }\end{array}$ & 82 & 18 \\
\hline
\end{tabular}


is very low and could not afford for paying for the waste disposal followed by $25.6 \%$ of the household heads felt that it is the duty of the government (Table 5).

Most of the households (86.5\%) preferred a monthly payment through collection tickets. Flat rate as a basis for payment for the improved service was preferred by $69.5 \%$ households and the rest preferred that payment had to be based on weight of wastes
(Table 6). But flat rate charge imposes a disproportionately large financial burden on households those who were generating low amount of waste.

\section{How much willing to pay}

The result of this study showed that the mean willingness to pay of households was Rs 59.92/month. Meanwhile the minimum and maximum willingness to pay of the house-

Table 4: Reason for willingness to pay (Multiple Response)

Reasons

The household believes that solid waste collection service improvement is important for the health of the household

The household believes that solid waste collection service improvement is important for a better quality of the environment

The household would like to take part with the improvement of solid waste management

The household have trust with the local government for improving the solid waste collection

The household sees improper solid waste disposal practices in current's service

The household believes solid waste collection could increase cleanliness of the municipality

\section{Percentage}

2.4

Table 5: Reasons for not willing to pay

\begin{tabular}{ll}
\hline Reasons & Percentage \\
\hline It is the duty of the urban council & 14.1 \\
It is the duty of the government & 25.6 \\
$\begin{array}{l}\text { The municipality is still clean and does not need to improve } \\
\text { service }\end{array}$ & 2.6 \\
Income is very low and could not afford & 35.9 \\
My house's waste had not made any problem to me & 12.8 \\
Volume and quantity is very low & 8.9 \\
\hline
\end{tabular}


holds was recorded to be only Rs 20.00/month and Rs 100.00/month respectively. The study result showed that $28.8 \%$ of the household would be willing to pay Rs.100.00/month or Rs. 50.00/ month for improved municipal waste collection services while $18.64 \%$ of the household would be willing to pay Rs $30.00 /$ month. $10.17 \%$ of the household would be willing to pay Rs 20.00 /month and very few percentage of the household $(1.7 \%)$ would be willing to pay Rs 40.00/month or Rs $75.00 /$ month for the improved municipal waste col- lection service (Table 7).

\section{Factors affecting household willingness to pay}

The logit regression results of factors influencing willingness to pay for improved waste management are presented in Table 8. The logistic regression gave a Nagelkerke $R$ square of about 0.565 shows moderately strong relationship between predictors and prediction. The log likelihood ratio statistic is

Table 6: Preferred payment method

\begin{tabular}{|c|c|c|}
\hline \multirow[t]{2}{*}{ Payment Method } & \multicolumn{2}{|c|}{$\begin{array}{l}\text { Households Willingness to Pa } \\
(\mathrm{No}=59)\end{array}$} \\
\hline & Frequency & Percentage \\
\hline \multicolumn{3}{|l|}{ Duration of Payment } \\
\hline Monthly & 51 & 86.5 \\
\hline Every Collection & 8 & 13.5 \\
\hline \multicolumn{3}{|l|}{ Payment Mode } \\
\hline Collection Tickets & 59 & 100 \\
\hline \multicolumn{3}{|l|}{ Payment Basis } \\
\hline Flat Rate & 41 & 69.5 \\
\hline Dependent on Weight of Wastes & 18 & 30.5 \\
\hline
\end{tabular}

Table 7. Distribution of the different amounts the households willing to pay

\begin{tabular}{lll} 
Amount of willingness to pay (Rs) & Frequency & Percentage \\
\hline 20 & 6 & 10.2 \\
30 & 11 & 18.6 \\
40 & 1 & 1.7 \\
50 & 17 & 28.8 \\
60 & 2 & 3.4 \\
70 & 2 & 3.4 \\
75 & 1 & 1.7 \\
80 & 2 & 3.4 \\
100 & 17 & 28.8 \\
\hline Total & 59 & 100 \\
\hline
\end{tabular}


significant at one percent. Therefore, it can be concluded that the logistic model used has integrity and is appropriate. The validity of the logistic model in estimating willingness to pay for improved waste disposal is consistent with related studies of Robson (1993).

Household size significantly and positively $(p<0.01)$ influences the household willingness to pay. Chuen-Khee and Othman (2002) pointed out that the more the number of people in the household, the more willing the household will appreciate a clean environment.

Household expenditure, significantly and positively $(p<0.1)$ influences the household willingness to pay. Quantity of waste generated, number of times disposing the waste and gender had a negative coefficient and were significant $(p<0.05)$. Aggrey and Douglason (2010) found that household expenditure, quantity of waste generated and consumer's level of education also pose a significant in-

Table 8: Factors affecting Household Willingness to pay

\begin{tabular}{|c|c|c|c|}
\hline Variables & $\begin{array}{l}\text { Coefficient } \\
\text { (Standard Error) }\end{array}$ & $\operatorname{Exp}(\mathbf{B})$ & P value \\
\hline Age of the Head of & $-0.04(0.04)$ & 0.96 & 0.309 \\
\hline \multicolumn{4}{|l|}{ Household } \\
\hline Household size & $1.47(0.51)$ & 4.33 & $0.004 * * *$ \\
\hline Household income & $0.001(0.0)$ & 1.00 & 0.44 \\
\hline Household expenditure & $0.003(0.00)$ & 1.00 & $0.08 *$ \\
\hline Quantity of waste & $-0.72(0.36)$ & 0.49 & $0.045^{*}$ \\
\hline $\begin{array}{l}\text { Number of times disposing } \\
\text { the waste }\end{array}$ & $-0.53(0.25)$ & 0.59 & $0.033 *$ \\
\hline Gender & $-2.69(1.069)$ & 0.07 & $0.012 *$ \\
\hline Government employment & 18. $07(0.9)$ & $7.055 \mathrm{E} 7$ & $0.00 * * *$ \\
\hline Private Employment & $18.05(0.85)$ & $6.895 \mathrm{E} 7$ & $0.00 * * *$ \\
\hline Self - employed & $19.29(0.81)$ & $2.378 \mathrm{E} 8$ & $0.00 * * *$ \\
\hline Business & $18.99(0.0)$ & $1.768 \mathrm{E} 8$ & . \\
\hline Unemployed & $34.94(6366.92)$ & $1.484 \mathrm{E} 15$ & 0.99 \\
\hline Closed container & $-14.19(3120.53)$ & $6.899 \mathrm{E}-7$ & 0.99 \\
\hline Open Container & $2.054(1.55)$ & 7.796 & 0.184 \\
\hline Plastic bags & $1.982(1.18)$ & 7.257 & $0.093 *$ \\
\hline Pile in the yard & $3.18(1.54)$ & 23.971 & $0.039 *$ \\
\hline Intercept & $-13.61(2.87)$ & & 0.000 \\
\hline
\end{tabular}

*Significant at 0.1 level

** Significant at 0.05 level

$* * *$ Significant at 0.01 level 
fluence on consumers willingness to pay. Aggrey and Douglason (2010) also pointed out that, the higher the generation of waste, the more the household faces the challenges of waste disposal and the greater the willingness to pay. A negative coefficient of gender indicates that female respondents are more willing to pay for improved solid waste management than males, since traditionally it is the role of women to clean the house and dispose the waste. This result leads credence to findings of Afroz et al (2009) and Aggrey \& Douglason (2010).

\section{CONCLUSION}

This study focused on analyzing the willingness to pay of the households for an improved household solid waste management service in Eravur Urban Council, Sri Lanka. Contingent Valuation method was used for valuation. Mean quantity of solid waste generated by households was rather high and amounts to $2.61 \mathrm{~kg} /$ day. Whereas average solid waste load of the municipality was $20,000 \mathrm{~kg}$. Majority $(75 \%)$ of the households were dumping the waste in Urban Council vehicles. And the rest were using different methods implying that there is a need for education to the respondents on the negative effects of inappropriate disposal methods. Fifty nine percent of the households were willing to pay and the rest were not willing to pay for an improved service and about $38.89 \%$ of the household heads stated that they wanted to pay for an improved service because they believe that solid waste collection service improvement is important for the healthy life of the household while $38.09 \%$ of the household heads stated that it is needed for a better quality of the environment. The study found that the households that are not willing to pay produced larger amount of waste when compared to households which were willing to pay for an improved municipal solid waste management service. Composting and recycling are viable options for the community in Eravur urban council as majority of the respondents had the knowledge and willing to participate in this programs.

Those who were willing to pay would like to pay a flat rate on monthly basis rather than for each collection. Urban council should take this into consideration when collecting the wastes. And the mean willingness to pay of households was Rs 59.92/month. The logistic regression results on the factors influencing willingness to pay for improved waste management revealed that household size significantly and positively influences the household willingness to pay may be due to the fact that the more the number of people in the household, the more willing the household will appreciate a clean environment while household expenditure, significantly and positively influences the household willingness to pay. Quantity of waste generated, number of times disposing the waste and gender had a negative coefficient and were significant. Since the households were willing to pay on average Rs.59.92 per month with different payment methods in the Eravur Urban Council area for solid waste management, it is recommended that Eravur Urban Council should take necessary action to develop their collection service. Further households should be educated on effective solid waste disposal through regular sensitization programmes by a collaborative effort of key stakeholders in the solid waste management such as local government, the private sector, Nongovernmental organizations and residents.

\section{REFERENCE}

Afroz R Hanaki K. and Hasegawa-Kurisu K 2009 Willingness to pay for waste management improvement in Daka city, Bangladesh. Journal of Environment Management 90 (2009) 492-502.

Aggrey N and Douglason GO 2010 Determinants of willingness to pay for solid waste management in Kampala 
City. Current Research Journal of Economic Theory, 2(3), 119.

Ashish T R and Uttam D 2013 Households Willingness to Pay for Improved Waste Management in Silchar Municipal Area: A Case Study in Cachar District, Assam. Journal Of Humanities And Social Science 6 (5): 21-31.

Bandara NJGJ and Hettiarachchi P 2008 Environmental Impacts with Waste Disposal Practices in a Suburban Municipality in Sri Lanka, International Journal of Environment and Waste Management, Special Issue: Case studies on landfill diversion of household waste.

Bartone CL and Bernstein J 1993 Improving Municipal Solid Waste Management in Third World Countries. Resources, Conservation and Recycling 8:43-5.

Chuen-Khee P and Othman J 2002 Household demand for solid waste disposal options in Malaysia. World Academy of Science, Engineering and Technology, (66), 1153-58.

Gunawardana EGW Basnayake BFA Shimada S Iwata T 2009 Influence of biological pre-treatment of municipal solid waste on landfill behaviour in Sri Lanka. Waste Manag Res 27(5): 456-462.

City Profile, Batticaloa, 2005.

Eravur Urban Council Report, 2014.

Inazumi $\mathrm{S}$ Ohtsu $\mathrm{H}$ Shiotani $\mathrm{T}$ Katsumi $\mathrm{T}$ 2011 Environmental assessment and accounting for the waste disposal stream in Bangkok, Thailand. J Mater Cycles Waste Manag 13:139-149.

Medina M 2010 Solid Wastes, Poverty and the Environment in Developing Country Cities Working Paper No. 2010/23.
Robson C. 1993 Real-World Research: A Resource for Social Scientists and Practitioner-Researchers, Blackwell, Malden, Mass, USA.

UNEP (United Nations Environment Program. 2004 The Use of Economic Instruments in Environmental Policy: Opportunities and Challenges. Geneva: UNEP.

Vidanaarachchi CK Yuen STS Pilapitiya S 2006 Municipal solid waste management in the Southern Province of Sri Lanka: problems, issues and challenges. Waste Manag 26:920-930.

Wijerathna DMCB Lee K Koide GT Jinadasa KBSN Kawamoto $\mathrm{K}$ Iijima $\mathrm{S}$ Herath BB Kalpage CS and Mangalika L 2011 Solid waste generation, characteristics and management within the households in Sri Lankan Urban areas. ICSBE2012/SBE-12-241.

Yusufu S Salimonu KK and Ojo OT 2007 Determinants of willingness to pay for improved household waste management in Oyo state, Nigeria, Journal of applied sciences 2(3) 233- 239.

Zurbrugg C 2003 Urban solid waste management in low-income countries of Asia, How to cope with the Garbage crisis. 